\title{
Hiehokasvattamoiden rakennusratkaisut
}

\author{
T.Kivinen ${ }^{1}$, K.Partanen ${ }^{2}$, S.Mönkkönen ${ }^{3}$, R. Kauppinen ${ }^{4}$, V-M.Tuure ${ }^{5}$, M.Lätti ${ }^{6}$ \\ ${ }^{1}$ MTT, Vakolantie 55, 03400 Vihti, tapani.kivinen@mtt.fi \\ ${ }^{2}$ Savonia AMK, Haukisaarentie 2, 74160 Iisalmi, kati.partanen@savonia.fi \\ ${ }^{3}$ Savonia AMK, Haukisaarentie 2, 74160 Iisalmi, seppo.monkkonen@ savonia.fi \\ ${ }^{4}$ Savonia AMK, Haukisaarentie 2, 74160 Iisalmi, risto.kauppinen@savonia.fi \\ ${ }^{5}$ TTS Tutkimus, Kiljavantie 6, 05200 Rajamäki, veli-matti.tuure@tts.fi \\ ${ }^{6}$ TTS Tutkimus, Kiljavantie 6, 05200 Rajamäki, markku.latti@tts.fi
}

\section{Tiivistelmä}

Nuorkarjan kasvatus tapahtuu perinteisesti kiinteänä osana lypsykarjanavetan toimintaa. Nuorkarjan kasvatus vie osan maidontuottajan resursseista: eläinten hyvinvoinnista pitää huolehtia, niitä pitää ruokkia ja ne tarvitsevat navetasta omat ryhmäkarsinansa, partensa ja lantakäytävänsä. Tie vasikasta tiineeksi hiehoksi kestää noin 2 vuotta, minkä jälkeen eläin vasta alkaa "maksaa vuokraa" kasvatusajastaan.

Maidontuotantoketjun tehostamiseen ollut tullut uusi toimintamalli, jossa nuorkarjan kasvatus voidaan ulkoistaa kolmannelle osapuolelle, joka tekee sitä ammattimaisesti keskittyen pelkästään hiehojen kasvatukseen. Ulkopuolista kasvattamoa voidaan tällöin kutsua hiehohotelliksi, koska kasvattajalla voi olla asiakkaina useampia lypsylehmätiloja. Toiminnan taloudellisuus perustuu siihen, että maidontuottaja voi keskittyä lypsäviin lehmiin ja hotellin pitäjä hyvien hiehojen kasvattamiseen. Maidontuottaja voi muuttaa nuorkarjapaikat lypsylehmille tai uudisrakentamisen tapauksessa suunnitella koko pihatto pelkästään lypsylehmille. Neliöt tulevat tällöin tuottavampaan käyttöön. Nuorkarjakasvattaja voi laskea kasvatuksen tarkan kulurakenteen ja asettaan kasvatuspäivän hinnan sellaiseksi, että maidontuottajan kannattaa se maksaa. Tavoitteena on win-win tilanne, josta molemmat osapuolet hyötyvät kohtuullisesti.

Nuorkarjan kasvatuksen ulkoistaminen sopii pienille maitotiloille, jotka miettivät tuotannon lopettamista. Ulkoistamistilanteessa uusia lehmäpaikkoja syntyy helposti ilman suuria investontikuluja. jolloin tuotannon laajentaminen on houkuttelevaa. Kasvatustiloiksi soveltuvia vanhoja navetoita löytyy, koska maidontuotannon lopettajia on runsaasti. Hotellitoiminta voisi olla maidontuotannon lopettamista harkitseville eräänlainen jäähdyttelyvaihe. Nuorkarjan kasvatus vanhoissa navettatiloissa ei juuri aiheuta lisäinvestointeja rakennukseen tai rakenteisiin.

Hiehohotelli -hanke on vuosina 2009 - 2011 tutkinut ja kehittänyt pohjaratkaisumalleja ammattimaiseen suuren mittakaavan nuorkarjakasvatukseen. Kokoluokkana on pidetty 180-paikkaista hotellia, joka voisi ottaa kasvatukseen kolmen robottitilan vasikat. Rakennusratkaisussa korostuu eri tiloilta tulevien vasikoiden tautipaineen torjunta. Tulokasryhmät sijoitetaan erilliseen tilaan, jotta bakteerien leviäminen isompaan kasvatushalliin estetään. 180-paikkaisesta hotellista on myös tuplausmalli 360paikkaiseksi kasvattamoksi. Edellisten lisäksi on suunniteltu kasvattamomalli, jossa sonnivasikat voidaan kasvattaa yhdessä hiehojen kanssa 6 kk ikään asti, jonka jälkeen ne oletetaan siirrettäväksi varsinaiseen pihvikasvattamoon. Sekakasvattamon oletetaan soveltuvan sellaisille tiloille, jotka haluavat laajentaa toimintaansa myös lihatuotannon puolelle.

Avainsanat: nuorkarjan kasvatus, ulkoistaminen, hiehohotelli, nuorkarjapihatto 


\section{Johdanto}

Hiehonkasvatuksen ulkoistaminen ja sen eriyttäminen maitotilojen ulkopuolelle, omaksi erilliseksi tuotantomuodokseen, antaa mahdollisuuksia saavuttaa parempaa kustannustehokkuutta ja kilpailukykyä maitotiloilla. Samalla se synnyttää uudenlaista liiketoimintaa kotieläintuotantoon ammattimaisen hiehonkasvatuksen muodossa. Hiehonkasvatuksen ulkoistamisen huomioon ottaminen jo rakennuksen suunnitteluvaiheessa vaikuttaa rakennuskustannukseen lypsykarjanavetoiden uudisrakentamisessa ja tilan tulevaan työnkäyttöön. Jos ulkoistamiseen päädytään, navettaan ei tarvitse rakentaa nuorkarjapaikkoja tai sitten ne tilat voidaan mitoittaa lypsylehmille. Hiehohotelli suunnitellaan pelkästään nuorkarjalle. Normaalisti vasikat saapuvat hotelliin ternijuottovaiheen jälkeen, mutta hapanjuottotilojen sijoitus hotelliin on mahdollista. Hotelli on myös mahdollista suunnitella joustavuusperiaatteella ja mitoittaa siten, että se on myöhemmin mahdollista muuttaa esimerkiksi robottipihatoksi.

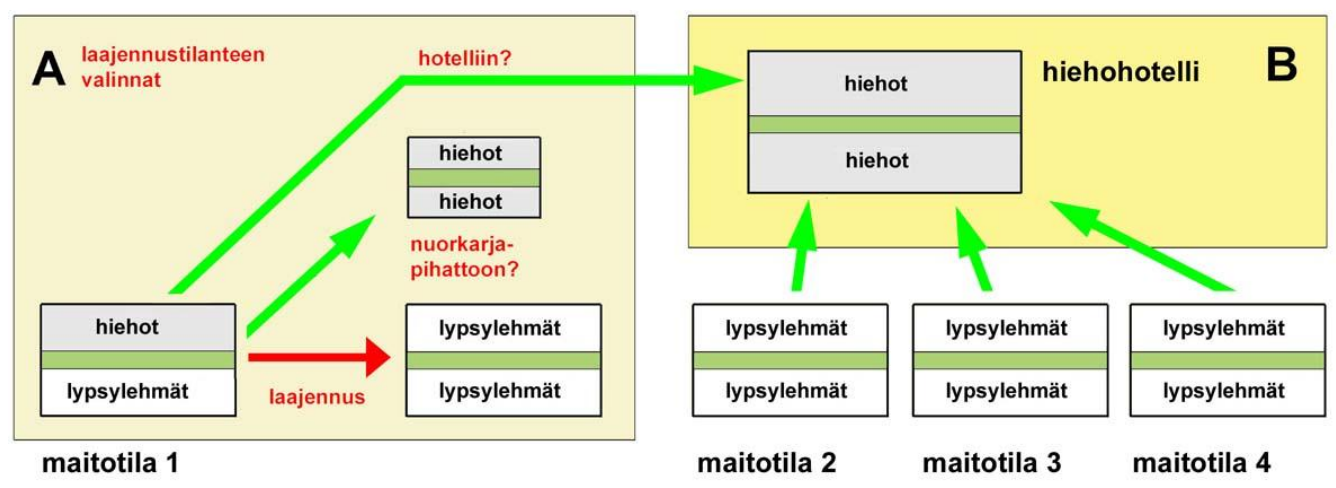

Kuva 1: Maitotilan laajennusvaiheessa joudutaan pohtimaan nuorkarjan sijoitusta: tehdäänkö lypsykarjapihaton läheisyyteen erillinen nuorkarjapihatto vai ulkoistetaanko kasvatus hiehohotelliin?

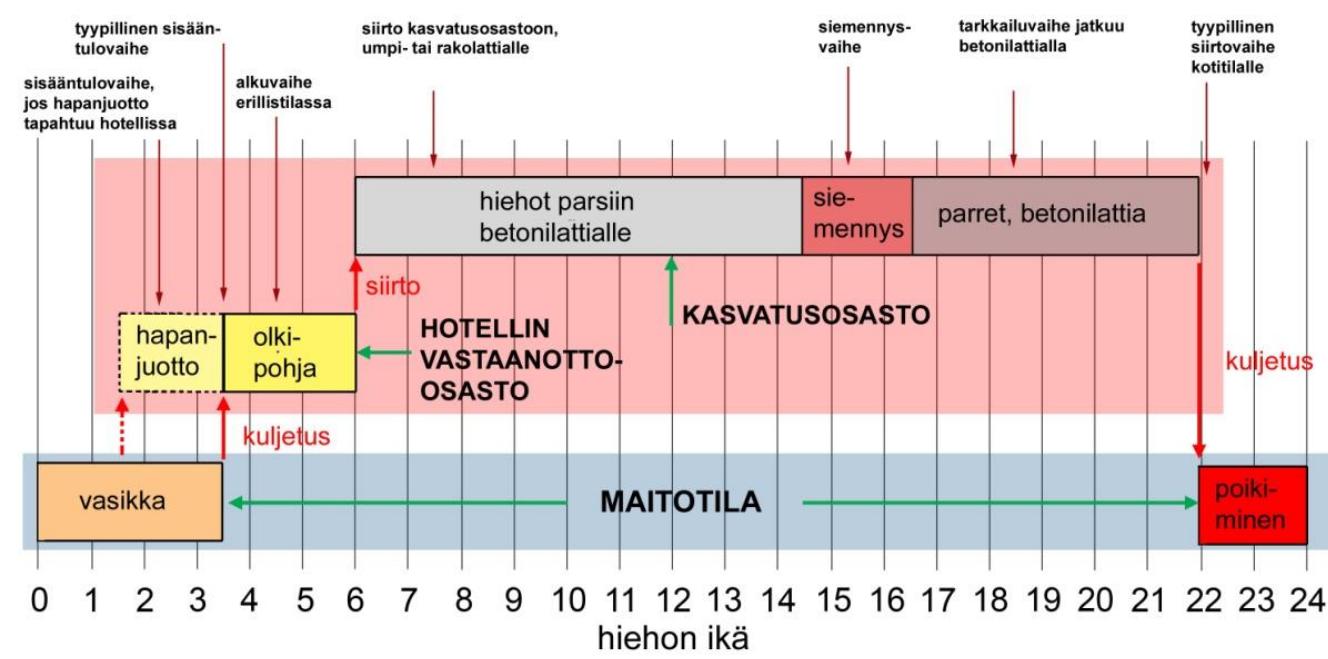

Kuva 2: Vasikan tie kotitilalta hotelliin ja takaisin tanskalaisen mallin mukaan.

\section{Hotellikasvattamo vanhasta navetasta}

Hiehokasvattamo voidaan toteuttaa olemassa oleviin vanhoihin lypsykarjarakennuksiin, jotka tyypillisesti ovat perinteisiä parsinavetoita. Maidontuotannosta luopuvia tiloja on nykyisellä kehitysvauhdilla keskimäärin 3 kpl joka päivä. Hiehokasvattamoksi sopivia rakennuksia on toisin sanoen runsaasti tarjolla. Kasvattamotoiminta sopii erittäin mainiosti entiselle maitotilalle, koska rakennukset ja rehuntuotannon koneet ovat käyttökunnossa ja osaaminen on tilalla tallella. 
Navetoista löytyy yleensä kaikki eläinpaikkavaihtoehdot, jolloin esimerkiksi 2-viikkoisten juottoikäisten vasikoiden vastaanotto onnistuu. Vanhan navetan rajoittavin tekijä on eläinpaikkojen lukumäärä, mikä määrittelee lähettävien tilojen karjakoon. Jos vanhassa navetassa on esimerkiksi 15 lypsylehmäpaikkaa, nuorkarjapaikkoja on saman verran, ja jos sonnit on kasvatettu samalla tilalla, paikkoja on vielä runsaammin. Eläinpaikkoja voi 15 lehmän navetassa olla yhteensä 30-40. Vasikoita lähettävänä maitotilana voi tällöin olla yksi 40-50 -lypsylehmän tai kaksi 15-20 -lypsylehmän maitotilaa.

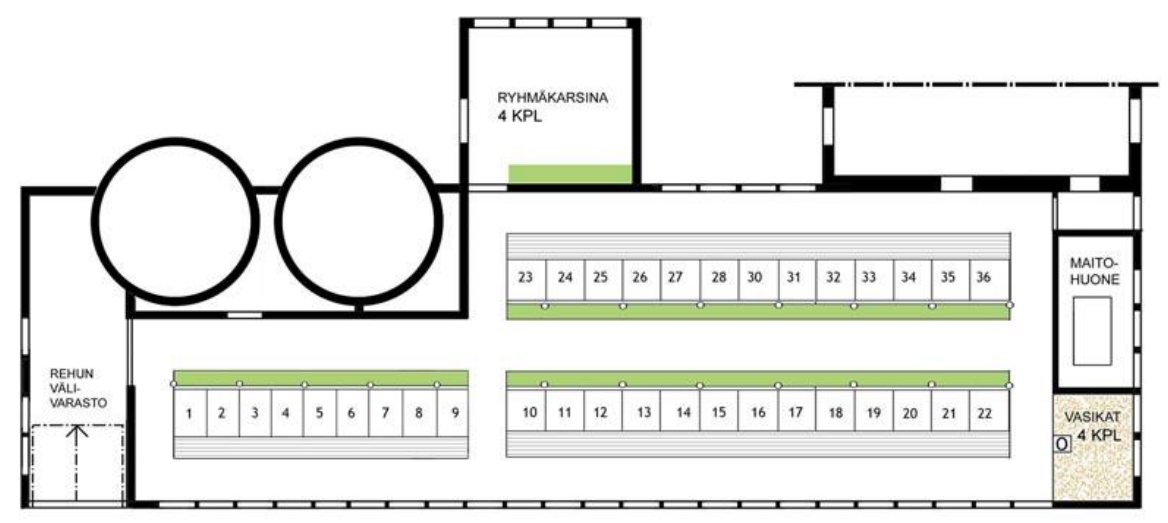

Kuva 3: 44-paikkainen hotelli. Navetan muuttaminen hotelliksi ei vaatinut mitään investointeja rakennukseen, rakenteisiin, kalusteisiin tai tilan koneistukseen.

Vanhojen rakennusten korjaus ja eläinpaikkojen laajentaminen riippuvat luonnollisesti kunkin kohteen olosuhteista ja rakennusteknisestä kunnosta. Jos suurempaa remontoitavaa ei ole, vähintäänkin perusteellinen sisäpesu voi olla tervetullut toimenpide. Kasvatuspaikkojen lisäämisessä pitää olla varovaisen laskelmallinen. Pienet sisäiset laajennukset kuten esimerkiksi lypsyaseman tai maitohuoneen muuttaminen eläinpaikoiksi voivat olla taloudellisesti järkeviä. Suurten rakennusosien tai rakenteiden purkaminen voi tulla turhan kalliiksi suhteessa syntyvien kasvatuspaikkojen määrään. Eläinpaikan hinta ei saa muodostua kohtuuttoman suureksi.

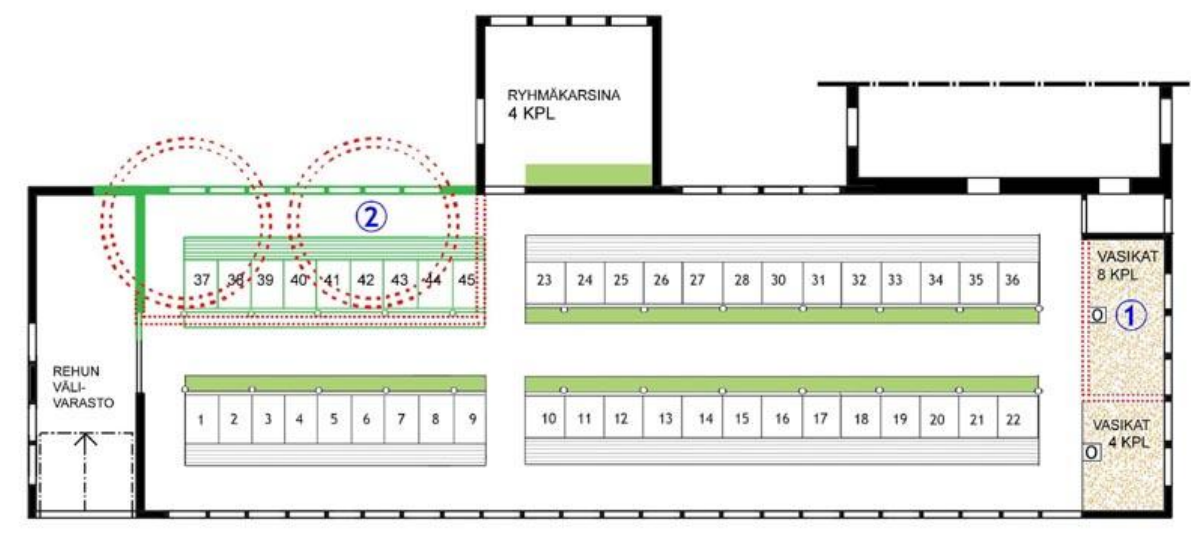

Kuva 4: Edellä olevan navettapohjan muutosajatuksia. Maitohuoneen purkaminen ja muutos uusiksi vasikkapaikoiksi on suhteellisen pieni toimenpide ja järkevästi toteutettavissa. Vanhojen aiv-siilojen purkaminen, uuden ulkoseinän ja katon rakentaminen 9 uuden kasvatuspaikan aikaansaamiseksi on puolestaan liian kallis investointi.

\section{Laajentava maitotila}

Nykymittapuun mukainen pieni maitotila voi laajentaa tuotantoansa ulkoistamalla hiehokasvatuksen lähialueella oleviin kasvattamoihin. Lehmäpaikkojen lisäys edellyttää yleensä muutostöitä. Vanhat nuorkarjapaikat on mitoitettu nuorkarjalle, jolloin parsipaikat on uudistettava lehmämitoille. Tämä merkitsee muutoksia lattiaan, lantaritilöihin ja parsikalusteisiin. Myös maidonkeräilyputkea pitää laajentaa ja kenties hankkia lisää lypsinyksikköjä. Vanha lantala on mitoitettu alkuperäiselle eläinjakaumalle. Kun lypsylehmien lukumäärä kasvaa, lantamääräkin lisääntyy. Lantalan riittävyys ja sen laajennustarve voikin 
olla suurin muutosinvestointia edellyttävä toimi. Yleensä kyse on marginaalisesta lisäystarpeesta, jolloin kannattaa miettiä erilaisia vaihtoehtoja. Lantalalaajennuksen sijasta säiliökapasiteettia voi olla helposti vuokrattavissa lähialueen lopettaneilla maitotiloilla, jolloin todellinen kustannus siirtyy investoinnista käyttökustannuksen puolelle.

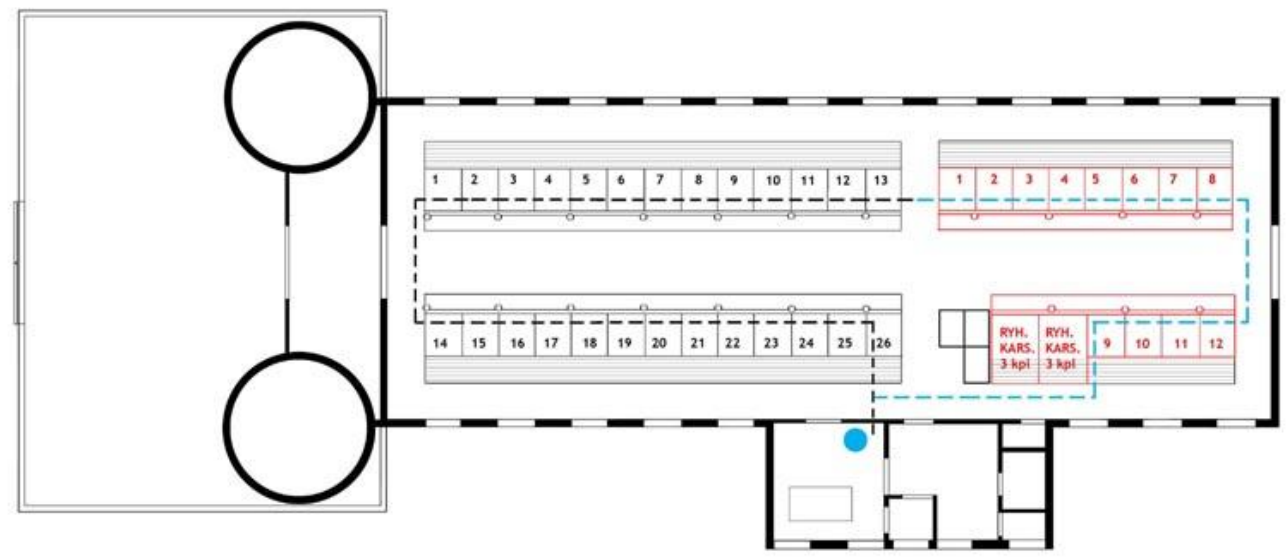

Kuva 5: Hiehokasvatuksen ulkoistava tila on muuttanut vanhat nuorkarjapaikat lypsylehmäpaikoiksi. Betonilattioiden muutostyöt, kalustemuutokset, uusi maitoputkisto ja lypsykoneen päivitykset ovat maksaneet noin $500 €$ uutta lehmäpaikkaa kohden. Maidontuotannon kapasiteettilisäys on ollut yli $50 \%$.

\section{Hiehohotelli uudisrakennuksena}

Uudisrakennuksen suunnitteluun vaikuttavat toiminnallisuus, mitoitus, hygienia, rakenteet ja talotekniikka sekä käytettävä ruokintatekniikka ja työsuoritukset. Tulevalla hotelliyrittäjällä on oltava näkemys kasvatuspaikkojen kysynnästä, minkä perusteella kasvattaja tekee investointipäätöksensä. Asiakastilojen lukumäärän olisi pysyttävä tautipaineen minimoimiseksi mahdollisimman pienenä. Parhain hygieeninen tilanne saavutetaan silloin, kun hotellitila voi kasvattaa vain yhden asiakastilan hiehoja. 2-4 asiakastilaa on sopiva, yli 5 tilaa muodostaa jo selvän riskitilanteen. Kasvatuspaikkojen lukumäärä syntyy asiakastilojen lukumäärän ja siellä olevien lypsylehmien määrien perusteella.

\section{Toiminnallinen periaate}

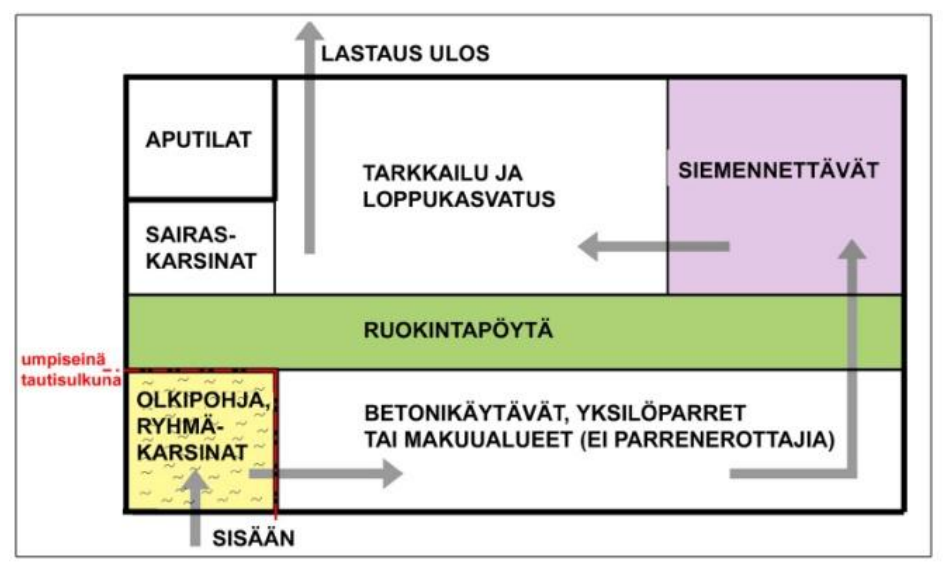

Kuva 6: Eläinliikenteen yleisperiaate

Toiminnallisessa määritellään etenemisestä ikävaiheesta ja Eläinliikenteen yleisperiaate voidaan kiteyttää lausumaan: yhdestä nurkasta sisään ja toisesta ulos. Sisääntulo-osasto eristetään päähallista kattoon asti ulottuvilla väliseinillä tautipaineen vähentämiseksi. Tautipaineen torjunta ja

hallinta ovatkin toiminnallisen suunnittelun lähtökohtia. Vasikat pyritään mahdollisuuksien mukaan ottamaan erilliseen vastaanottotilaan, jossa kontaktit hotellin kasvatusosastoon ovat vähäisiä tai niitä ei ole ollenkaan. Vasikat otetaan olkikuivitetulle kestokuivikepohjalle hyvinvointinäkökulman vuoksi. Vastaanotto-osastossa eri tiloilta tulleiden vasikoiden bakteerikanta sekoittuu ja mahdollisiin tautitapauksiin voidaan puuttua tässä vaiheessa. 
Tutkimuksen tuloksena on kehitetty 180-paikkaisen hotellirakennuksen periaate ja pohjaratkaisumalli. 180 kasvatuspaikan tarpeen lasketaan syntyvän 3 lypsyrobottitilan vasikoista, ja näin se vastaisi sitä hotellimallia, jolle tällä hetkellä Suomessa olisi eniten kysyntää. Hotellimalli oletetaan rakennettavaksi tilalle, jossa ei välttämättä ole aikaisempaa lypsykarjarakennusta, jolloin rakennukseen on syytä varata toimisto-, wc-, puku- ja varastotilaa. Esitettävät pohjaratkaisumallit perustuvat tanskalaisiin mitoitussuosituksiin. Ruokintakäytävän molemmin puolin asettuvat osastot on mitoitettava kunkin puoliskon vanhimman eläinryhmän vaatimin mitoin.

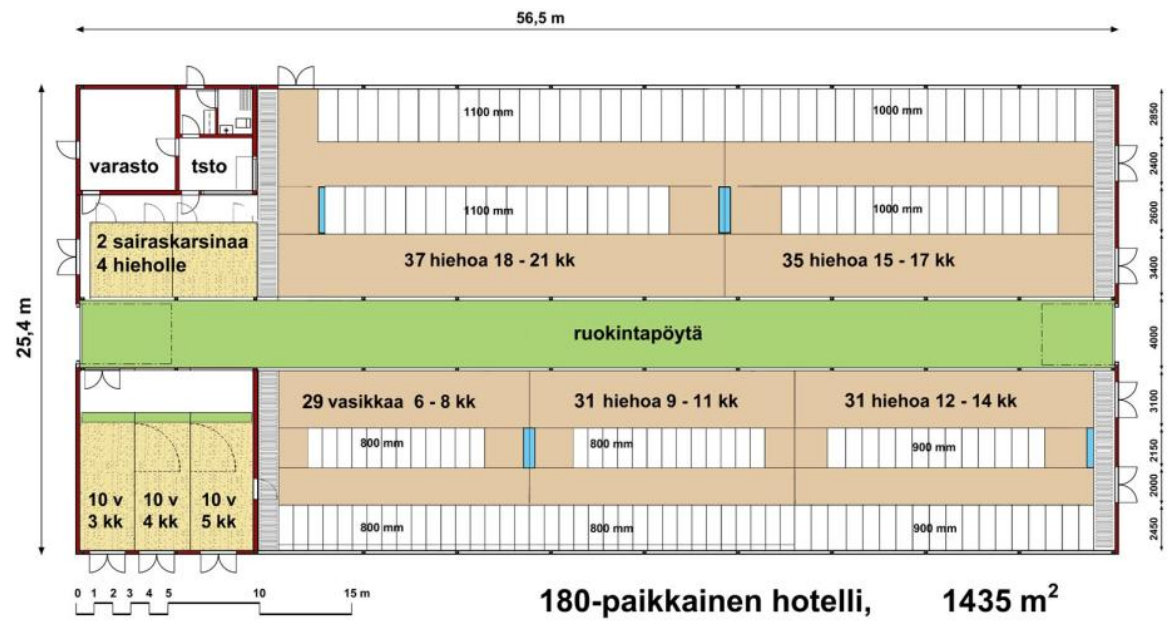

Kuva 7: 180-paikkaisen hotellirakennuksen mallipohjaratkaisu läpiajettavalla ruokintapöydällä..

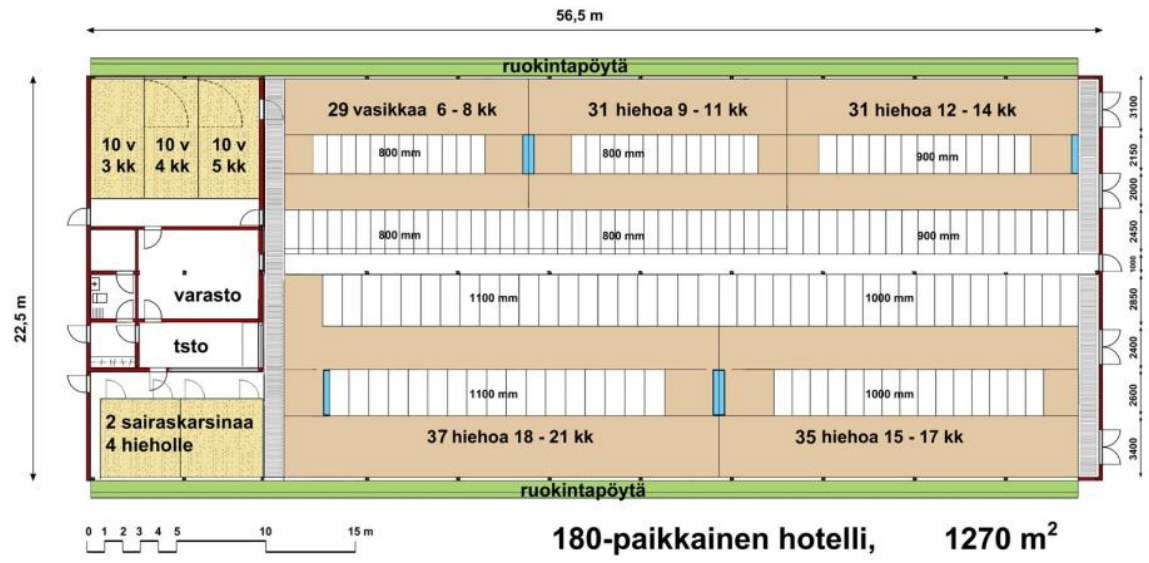

Kuva 8: 180-paikkaisen hotellirakennuksen mallipohjaratkaisu ulkopuolisilla visiiriruokintapöydillä.

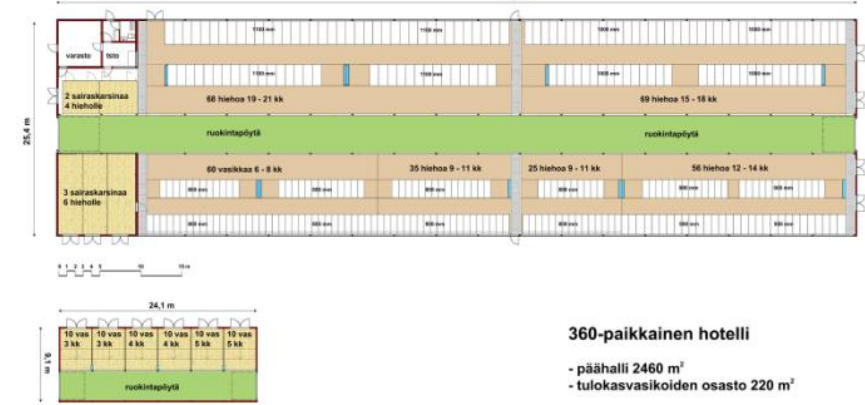

Kuva 9: Rakennus on suunniteltava laajennettavaksi. Se tarkoittaa rungon pidentämistä pituussuuntaisesti, jolloin karsinajakoja täytyy muuttaa suurempia ikäryhmiä palveleviksi. Tämä edellyttää tarkkuutta vesialtaiden sijoittelussa, jotta niitä ei tarvitse siirrellä laajennusvaiheessa. 180paikkainen hotelli on laajennettu 360-paikkaiseksi. Ykkösvaiheen pääty on purettu ja rakennusta on jatkettu. Vanhan osan muutokset rajoittuvat parsien levennyksiin, vesialtaat pysyvät vanhoilla paikoillaan. Vanha vasikoiden vastaanotto-osasto muutetaan sairaskarsinoiksi eläinmäärän lisäyksen suhteessa. Tulokasvasikoille rakennetaan tässä vaiheessa oma ja erillinen katos, johon sijoitetaan $6 \mathrm{kpl} 10$ vasikan täytepohjakarsinoita. Ne voidaan yksilöllisesti täyttää ja tyhjentää. Ruokintapöytä on katettu, jotta talven lumi ei haittaa ruokintaa ja samalla se vähentää vetoisuutta. Päähallin jatko-osa noudattaa vanhan osan käytäväleveyksiä ja parsialueiden syvyyksiä. 
Muuntojouston voi viedä niinkin pitkälle, että hotellin voi tarvittaessa muuttaa robottipihatoksi. Tällöin lypsylehmille soveltuvat vain yli $15 \mathrm{kk}$ hiehoille osoitetut tilat ja nekin vain silloin, jos ne on jo etukäteen mitoitettu lypsylehmille. Nuorkarjan (6-14 kk) tilat jäisivät tällöin nuorkarjan osastoiksi.

\section{Rakenteet}

Edellä esiteltyjen hallien runkorakenteena on lähtökohtaisesti pidetty pilari-palkki- tai kehäratkaisua. Ulkoseinä- ja keskialueen pilarit voivat olla teräs- tai puupilareita tai niiden yhdistelmiä detaljoidun rakennesuunnitelman mukaisesti. Vaihtoehtoisesti runko voi olla teräksinen kolminivelkehä. Kehäjakona on käytetty 5-6 m, mikä sopii hyvin esimerkiksi profiilipellille vesikaton kantavana rakenneosana. Vesikatto lämpöeristetään $5-15 \mathrm{~cm}$ eritekerroksella eristeen laadusta riippuen. Vesikatteeksi sopii huopa, yksikerroskate tai pelti. Päädyt rakennetaan umpinaisiksi ja lämpöeristetään. Nosto-ovet ovat eristettyjä alumiiniovia, ikkunat kennolevyä. Lattiat ovat betonia, lantakäytävät pääsääntöisesti kiinteitä umpilattioita, joissa on lantaraapat. Lattioita ei lämpöeristetä.

\section{Lannanpoisto}

Olkipohja - betonilattia kaksijakoisuus edellyttää kuivalannan ja lietteen varastointia ja käsittelyä. Olkipohja edellyttää lisäksi olki- tai vaihtoehtoisesti turvevarastoa sekä niiden levitykseen soveltuvaa kalustoa. Olki/turvepohjaa lisätään viikoittain, mutta poiston tiheys voi vaihdella. Yleisesti olki/turvepohja hoito edellyttää traktorin etukuormaajaa tai vastaavaa pienkuormaajaa, jolle on varattava vapaa ajolinja ja leveät ovet tyhjennettäviin karsinoihin.

Betonikäytävät voivat olla joko umpilattiaisia tai ritiläpalkkiratkaisuja. Viime mainittujen suhteen on muistettava, että vasikan/hiehon lanta on kuivaa, jolloin sen kulku kanaaleissa voi olla sitkeätä. Tanskalaisilla hotellitiloilla on kanaaleihin jouduttu lisäämään vettä lannan kulun edistämiseksi.

Kiinteät lantakäytävät varustetaan raapoilla. Etukauhalla (bobcat tai vastaava) tapahtuva puhdistus on hankalaa, koska eläimiä ei siirrellä osastoista toisin kuin lypsylehmiä, jolloin osaston puhdistus tapahtuu lypsyjen aikana.

Lannanpoistoon liittyy muutama hygienianäkökulma. Tarttuvia sorkkasairauksia esiintyy yleensä vanhemmilla hiehoryhmillä. Tällöin raappa voi siirtää taudinlähdettä nuorempien osastoihin ja aiheuttaa niiden sairastumista. Tautien leviäminen ei rajaudu pelkästään raappaan. Myös saappaiden mukana voi levitä sairauksia. Siksi eläinten tarkkailu kannattaa tehdä nuoremmista vanhempiin päin kiertäen. Sorkkasairauksien torjumiseksi ritiläpalkki on parempi valinta, koska lanta liikkuu kanaalissa.

Eläinten siirrot kannattaa rytmittää ja keskittää asiakastilojen kanssa määriteltyihin ajankohtiin. Tavoitteena on keskitetty "vaihtopäivä", hieman lomahotellin tapaan kerran viikon tai kahden välein. Vaihtopäivänä hotellissa on työhuippu. Vanhin ryhmä lastataan, ja sen jälkeensä jättämä ritiläpalkkiosasto pestään ennen kuin nuorempi ryhmä päästetään pestyyn osastoon. Sen jälkeen pestään seuraava osasto ja sitä seuraava ja edetään nuorimpaan betonipalkkiosastoon. Näin estetään mahdollisten sorkkasairauksien leviäminen nuorempien siirtyessä vanhemmilta vapautuneisiin osastoihin. Sama vaihtopäivän työhuippu toteutuu myös raapoin varustetussa umpilattiahotellissa, mutta lattioiden pesu ei ole välttämätöntä, koska raappa liikkuu osastoista toiseen joka tapauksessa.

\section{Ilmanvaihto}

Hotellirakennus oletetaan tehtäväksi ns. viileäpihattona, jossa katto ja päätyseinät ovat lämpöeristetyt. Ilmanvaihto järjestetään painovoimaisesti verhoseinillä ja hormeilla. Vasikoiden tulo-osasto on kattoon asti ulottuvilla väliseinillä erotettu päähallista, jolloin sen ilmanvaihto on järjestettävä itsenäisesti. Tulo-osaston täyttöovien yläpuolella on verho- tai kennopaneelivyöhyke ja katolla erillishormit.

\section{Rakennuskustannukset}

180-paikkaiselle hotellille laskettiin rakennuskustannukset kesän 2010 hintatasolla. Lattiaksi valittiin umpilattia ja lantaraapat, koska se on halvempi ratkaisu ritiläpalkkeihin ja kanaaleihin verrattuna. Ruokintapöytä on keskellä rakennusta ja kokonaisala $1435 \mathrm{~m}^{2}$. Rakennuksen hinnaksi tuli $332600 €$ ja 
toimintainvestointien osuudeksi $83380 €$, yhteensä $408940 €$. Eläinpaikan hinnaksi tuli $2310 € /$ ep ja neliöhinnaksi $290 € / \mathrm{m}^{2}$.

Visiiriruokintaratkaisussa rakennettavat neliömetrit vähenevät, mutta toimintainvestoinnit pysyvät samoina. $1270 \mathrm{~m}^{2}$ kokoisen hotellin rakennuskustannus on $299470 €$, ja kokonaiskustannus toimintainvestointien kanssa $382850 €$. Eläinpaikan hinnaksi tulee tällöin $2127 €$ ja rakennuksen neliöhinnaksi $301 € / \mathrm{m}^{2}$.

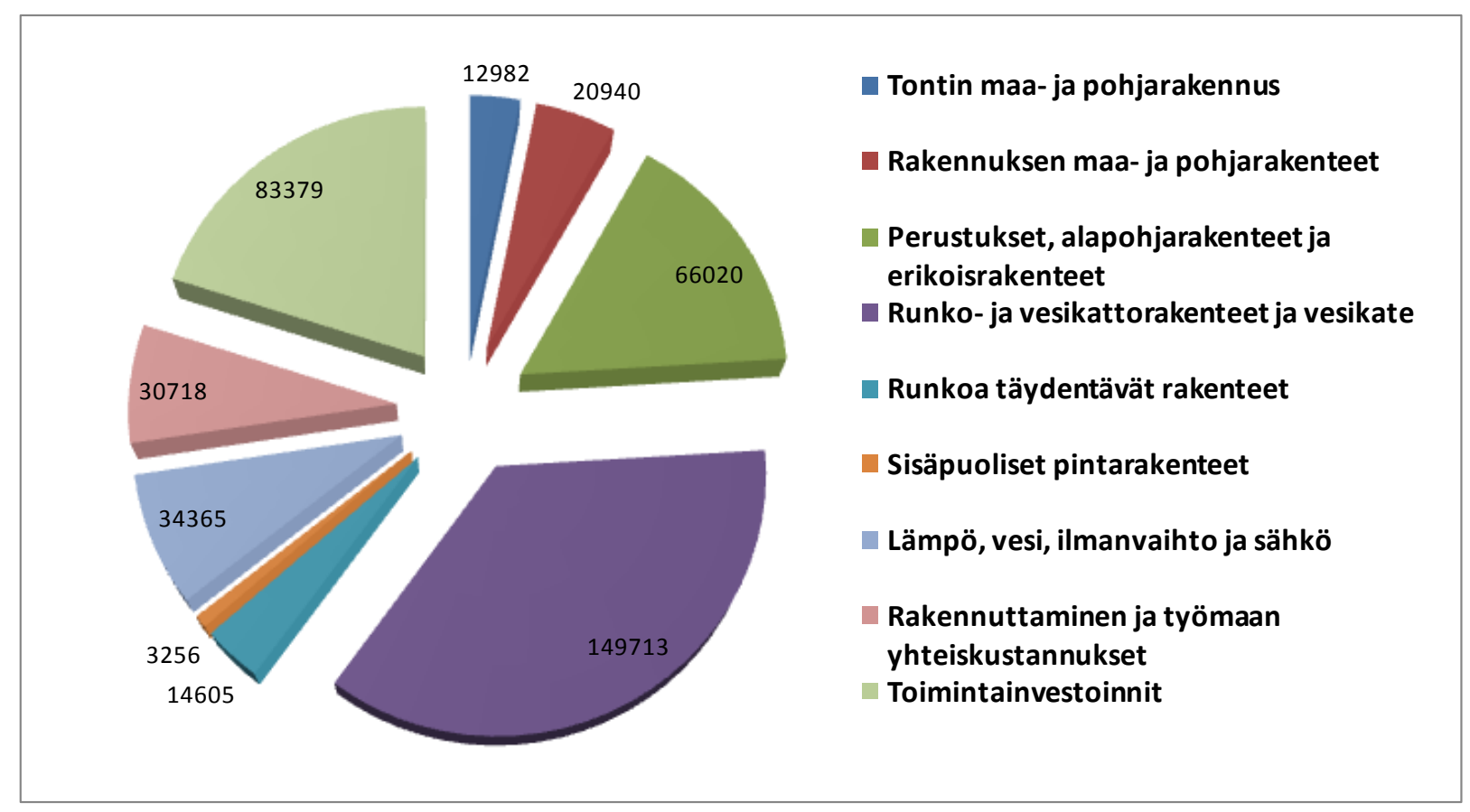

Kuva 9: 180-paikkaisen hotellin rakennuskustannusten $408940 €$ jakauma rakennusosittain $1435 \mathrm{~m}^{2}: 11 \mathrm{e}$.

\section{References}

Marcher A.M, 2008. Kviehoteller. Dansk Landbrugsrådgivning Landscentret, Århus, Danmark, 44 pp.

Turunen, M., Reinikainen, V., Patajoki, M., Wahlroos, H:, 2008. Ulkoistettu hiehonkasvatus. Jyväskylän ammattikorkeakoulu, Luonnonvarainstituutti, Finland, 54 pp.

Kauppinen, R., Partanen, K., Viitala, H., Remes, K., Mönkkönen, S., Tuure, V., Palva, R., Lätti, M., Kaila, E., Kivinen, T., Huuskonen, A. 2010. Hiehohotelli - hiehokasvatuksen ulkoistaminen. In: Toim. Anneli Hopponen. Maataloustieteen Päivät 2010, 12.-13.1.2010 Viikki, Helsinki, Finland, presentations, posters. Suomen maataloustieteellisen seuran tiedote $26.4 \mathrm{p}$.

Partanen, K., Kauppinen, R., Viitala, H., Mönkkönen, S., Lätti, M., Tuure, V., Kivinen, T., Huuskonen, A., JokiTokola, E., Rainio, V., Ruoho, O., Repo, M. 2010. Kannattavuutta hiehonkasvatukseen. Nauta 40, 4/2010, Finland, pp. 63-65.

Partanen, K., Kauppinen, R., Viitala, H., Mönkkönen, S., Lätti, M., Tuure, V., Kivinen, T., Huuskonen, A., JokiTokola, E., Rainio, V., Ruoho, O., Repo, M. 2010. Hiehot kasvattamoon - mikä muuttuu lypsykarjatilalla. Nauta 40, 3/2010, Finland, pp. 84-86.

Kivinen, T. 2010. Hiehohotellit tanskalaisittain. Nauta 40, 5/2010, Finland, pp. 59-61. 